\title{
Correlations between in situ denitrification activity and nir-gene abundances in pristine and impacted prairie streams
}

\author{
David W. Graham ${ }^{a}, \mathrm{~b}$, Clare Trippett ${ }^{\mathrm{b}}$, Walter K. Dodds ${ }^{\mathrm{C}}$, Jonathan M. O'Brien ${ }^{\mathrm{C}}$, Eric B.K. \\ Bannerc, lan M. Head ${ }^{b}$, Marilyn S. Smithd, Richard K. Yang ${ }^{a, d}$, and Charles W. Knappa,b, ${ }^{*}, 1$ \\ aDepartment of Civil, Environmental and Architectural Engineering, University of Kansas, \\ Lawrence, KS 66045, USA \\ bSchool of Civil Engineering and Geosciences, Newcastle University, Newcastle upon Tyne, NE1 \\ 7RU, United kingdom \\ 'Division of Biology, Kansas State University, Manhattan, KS 66506, USA \\ ${ }^{\mathrm{d} D e p a r t m e n t}$ of Microbiology, Molecular Genetics, and Immunology, University of Kansas Medical \\ Center, Kansas City, KS 66160, USA
}

\begin{abstract}
Denitrification is a process that reduces nitrogen levels in headwaters and other streams. We compared nirS and nirK abundances with the absolute rate of denitrification, the longitudinal coefficient of denitrification (i.e., $K_{d e n}$, which represents optimal denitrification rates at given environmental conditions), and water quality in seven prairie streams to determine if nir-gene abundances explain denitrification activity. Previous work showed that absolute rates of denitrification correlate with nitrate levels; however, no correlation has been found for denitrification efficiency, which we hypothesise might be related to gene abundances. Watercolumn nitrate and soluble-reactive phosphorus levels significantly correlated with absolute rates of denitrification, but nir-gene abundances did not. However, nirS and nirK abundances significantly correlated with $K_{d e n}$, as well as phosphorus, although no correlation was found between $K_{d e n}$ and nitrate. These data confirm that absolute denitrification rates are controlled by nitrate load, but intrinsic denitrification efficiency is linked to nirS and nirK gene abundances.
\end{abstract}

\section{Keywords}

Denitrification; Nitrogen-removal; nirS; nirK; Sediment; Water-column; qPCR

\section{Introduction}

Urbanization and human land uses such as agriculture have resulted in increased levels of bio-available nitrogen $(\mathrm{N})$ in streams and rivers (Seitzinger et al., 2006). Increasing $\mathrm{N}$ alters the biotic integrity of streams (Dodds and Welch, 2000) in addition to causing significant eutrophication in downstream $\mathrm{N}$-limited waters, such as larger rivers, lakes and marine receiving waters (Rabalais, 2002). Despite increasing N loads, counterbalancing in-stream $\mathrm{N}$-suppression mechanisms exist, including denitrification, which is the microbiologically-

\footnotetext{
(C) 2010 Elsevier Ltd. All rights reserved.

*Corresponding author. charles.knapp@ strath.ac.uk (C.W. Knapp). ${ }^{1}$ David Livingstone Centre for Sustainability, Department of Civil Engineering, Graham Hills Building, 50 Richmond Street, University of Strathclyde, Glasgow, G1 1XN, United Kingdom. Tel.: +44 (0) 141548 3351; fax: +44 (0) 1915532066.
} 
mediated anoxic reduction of nitrate $\left(\mathrm{NO}_{3}^{-}\right)$to nitrous oxide $\left(\mathrm{N}_{2} \mathrm{O}\right)$ and nitrogen gas $\left(\mathrm{N}_{2}\right)$ (Galloway et al., 2003). Unfortunately, what controls rates of in situ denitrification and efficiency is only moderately understood because the abundance and function of denitrifying organisms are difficult to determine, largely because of the wide array of microorganisms capable of this function (Philippot and Hallin, 2005; Davidson and Seitzinger, 2006; Wallenstein et al., 2006; Seitzinger, 2008), and environmental conditions that influence rates are not well defined (Wallenstein et al., 2006). Further, direct measurement of in situ denitrification is not trivial because background dissolved $\mathrm{N}_{2}$ levels are often very high relative to denitrification rates, which makes denitrification-specific signal detection difficult. As such, limited data exist relating responsible microorganisms, habitat conditions, and ecosystem-level denitrification rates and efficiencies, which are all critical to develop strategies that promote or retain denitrification in streams.

To address this broad question, Mulholland et al. $(2008,2009)$ performed an extensive evaluation of $\mathrm{N}$-cycle reactions in streams, including denitrification, which spanned 8 regions, 72 headwater streams, and pristine, agricultural, and urban watersheds across North America (Lotic Intersite Nitrogen eXperiment; LINX II). Overall, these studies showed that absolute stream denitrification rates increased with increasing $\left(\mathrm{NO}_{3}^{-}\right)$levels. However, relative nitrate-removal rates are often lower in streams with high $\left(\mathrm{NO}_{3}^{-}\right)$loadings, implying $\mathrm{N}$-polluted streams tend to remove proportionally less $\left(\mathrm{NO}_{3}^{-}\right)$than pristine streams (i.e., they were less efficient;Mulholland et al., 2009; O'Brien et al., 2007). Thus, although high rates of denitrification occur in the streams with high $\mathrm{N}$ levels, $\mathrm{N}$-removal tends not to be efficient and consequential downstream $\mathrm{N}$-transport still occurs. Unfortunately, previous work on these streams only provided generic descriptions of microbial function (e.g., community respiration, gross primary production, the extent of periphyton) and no detailed quantification of in situ organisms or genes responsible for denitrification was performed (Mulholland et al., 2008, 2009). As such, we undertook a complimentary study with LINXII to determine whether relevant gene abundances and denitrification potential might better explain denitrification activity, especially intrinsic efficiency, in streams with different $\mathrm{N}$ loadings (Mulholland et al., 2009; O'Brien et al., 2007). Specifically, genes were quantified in seven prairie streams, which were associated with the non-heme-containing (nirS) and copper-containing (nirK) nitrite-reductases that encode the key enzyme classes responsible for the conversion of $\mathrm{NO}_{2}^{-}$to $\mathrm{NO}$ within the denitrification pathway (Philippot, 2002;

Tavares et al., 2006). Targeting such genes has been used previously to determine denitrifier community composition (Braker et al., 1998; Philippot and Hallin, 2005; Henry et al., 2006; Wallenstein et al., 2006; Knapp et al., 2009) and also explain related N-cycle phenomena.

Quantitative real-time PCR (qPCR) was used for gene detection because it is rapid, detects genes in both culturable and non-culturable species, and it is quantitative, which allows statistical analysis between gene levels and ecosystem function. Our ultimate goal here was to quantify gene abundances of the two key nir genes as surrogates for denitrifier population numbers, and use these gene abundances to determine whether they explain ecosystem-level denitrification rates and efficiencies in the streams. Streams were investigated with broadly differing denitrification activities for comparison, including highly pristine streams to those heavily impacted by agricultural or urban activity.

\section{Materials and methods}

\subsection{Denitrification determinations}

This current study examined seven streams, including: two pristine streams (Kings-N4D and Shane Creeks) at Konza Prairie Biological Station (Kansas, USA); two agricultural streams (Ag-North and Swine Creeks); and three urban streams ("The Ditch", Campus, and Little 
Kitten Creeks). Details about the streams and methods used to quantify in situ denitrification are provided elsewhere (O'Brien et al., 2007). In summary, the size of the streams varied with widths between 0.8 and $3.3 \mathrm{~m}$, average depths from 2 to $14 \mathrm{~cm}$, and reaches from 125 to $1000 \mathrm{~m}$ in length. Flow velocities varied between 0.9 and $6.7 \mathrm{~m} / \mathrm{min}$.

Denitrification rates were quantified by monitoring isotopic ${ }^{15} \mathrm{NO}_{3}^{-},{ }^{15} \mathrm{~N}_{2} \mathrm{O}$, and ${ }^{15} \mathrm{~N}_{2}$ levels in each stream after enrichment with $\mathrm{K}^{15} \mathrm{NO}_{3}\left(\delta\right.$ enrichment of $20,000 \&$ of stream $\mathrm{NO}_{3}^{-}$ levels) (O'Brien et al., 2007). Samples for water-column ${ }^{15} \mathrm{NO}_{3}^{-}$were collected at 6 stations along the stream reach $(+12 \mathrm{~h}$ and $+23 \mathrm{~h}$ during release). Samples were filtered (Whatman GF/F) and analysed using an adaptation of the ammonia diffusion method following nitrate reduction (Sigman et al., 1997) and mass spectrometry on a ThermoFinnigan Delta Plus instrument. Gaseous $\mathrm{N}$ samples were also collected using plastic syringes and were allowed to equilibrate with $20 \mathrm{~mL}$ ultra-pure helium for $5 \mathrm{~min}$; the gases were then collected in 12$\mathrm{mL}$ exetainer vials, and ${ }^{15} \mathrm{~N}_{2}$ and ${ }^{15} \mathrm{~N}_{2} \mathrm{O}$ concentrations were determined by mass spectrometry (Hamilton and Ostrom, 2007).

Actual rates of denitrification were calculated using the longitudinal flux model based on ${ }^{15} \mathrm{~N}_{2}$ measurements as previously described (Mulholland et al., 2004). The two measures of denitrification used here were total denitrification, which is the sum of the mass rate of formation of ${ }^{15} \mathrm{~N}_{2} \mathrm{O}$, and ${ }^{15} \mathrm{~N}_{2}$ per unit stream area $\left(\mathrm{mg}-\mathrm{N} \mathrm{m}^{-2}\right.$ day $\left.^{-1}\right)$, and the coefficient of denitrification $\left(K_{\text {den }} ; \mathrm{m}^{-1}\right)$, which describes the intrinsic longitudinal conversion of $\mathrm{NO}_{3}^{-}$to $\mathrm{N}_{2}$ and $\mathrm{N}_{2} \mathrm{O}$ along a stream reach and provides an optimal denitrification rate coefficient for given environmental conditions (O'Brien et al., 2007). These two measures differ in that total denitrification is the absolute mass rate of denitrification in a stream, which is biased by both the ambient $\mathrm{NO}_{3}^{-}$level and stream width, whereas $K_{d e n}$ reflects the intrinsic rate of $\mathrm{NO}_{3}^{-}$loss per unit distance along the stream independent of $\mathrm{N}$ level or stream size. This parameter is calculated from longitundal flux of ${ }^{15} \mathrm{~N}_{2}$ over the stream reach (O'Brien et al., 2007; Mulholland et al., 2008) and is inversely related to the percent removal of $\mathrm{N}$ from the stream along the reach according to $\% \mathrm{~N}-$ Removal $=\left(1-e^{k} d e n \cdot 1000\right) \cdot 100\left(\mathrm{O}^{\prime}\right.$ Brien et al., 2007).

\subsection{Water-quality determinations}

Water-column samples were collected and analysed for water chemistry. $\mathrm{NO}_{3}^{-}$, total ammonia $\left(\mathrm{NH}_{4}^{+}\right)$and soluble-reactive phosphorus (SRP) were determined using a Technicon auto-analyzer (APHA et al., 1995). Dissolved organic carbon (DOC) concentrations were determined with a Shimadzu TOC5000 high temperature catalysis method. Measurements of ecosystem metabolism, gross primary production (GPP) and community respiration (CR), were calculated from diurnal changes in dissolved oxygen and water temperature values measured by YSI data sondes at a single station (Bott, 1996).

\subsection{Sample collection for gene analysis}

Samples for the quantification of nirS and $\operatorname{nirK}$ genes were collected at least in triplicate from a minimum of four sections along each stream approximately $23 \mathrm{~h}$ after ${ }^{15} \mathrm{~N}$ tracer addition. Specifically, water-column samples were collected aseptically in bottles and kept on ice. At the laboratory, samples were homogenized by inverting the bottles at least 3 times, and $10 \mathrm{~mL}$ were centrifuged for $10 \mathrm{~min}(10,000 \times g)$; the pellets were retained for DNA extraction.

Sediment cores were collected from 3 streams (King's N4D, Campus and Ag-North) by inserting a liquid-nitrogen filled copper pipe (pinched at the bottom) into the stream sediment; basically, sediment and water were frozen surrounding the pipe in real-time and 
then were withdrawn intact from the stream bed. Sediments were immediately sectioned in $1-\mathrm{cm}$ intervals $(0-3 \mathrm{~cm}$ depth) and stored frozen in the field. When coring was not possible (due to substrate conditions or sampler availability), a 15-cm diameter PVC tube sampler was inserted $3-\mathrm{cm}$ into surface sediments. The resulting core was re-suspended into local surface water and handled similar to the water-column samples (except $2 \mathrm{~mL}$ were centrifuged and pelleted) (Knapp et al., 2009). Sediment gene abundance values were corrected for water-column values (which were often negligible).

Water-column samples $(50-100 \mathrm{~mL})$ were filtered onto pre-weighed glass fiber filters, dried to constant weight at $103{ }^{\circ} \mathrm{C}$ and re-weighed to determine total suspended solids (TSS). As with the sediment core samples, approximately $0.5 \mathrm{~g}$ (wet-weight) were dried and reweighed for dry-weight determinations (APHA et al.,1995).

\subsection{DNA extraction and analysis}

DNA samples were extracted using the MoBio UltraClean Soil DNA kit (Carlsbad, CA, USA) according to manufacturer's instructions. Before PCR analysis, DNA extracts were diluted (either 1:10 or 1:100) with molecular-grade water to minimize the presence of PCR inhibitors. Portions of nirS and nirK genes were quantified using primers nirS1F/nirS6R and nirK1F/nirK5R (Braker et al., 1998). Reactions were performed on either a Roche (Burgess Hill, UK) Light Cycler or a BioRad iCycler (Hercules, CA) qPCR system (Knapp et al., 2009). Each $25 \mu \mathrm{L}$ reaction mixture combined $2 \mu \mathrm{L}$ of template DNA, primers (700 nM) and PCR reagent (either Roche Faststartplus SYBR Green or BioRad iQ solution). Reaction conditions involved initial DNA denaturation $\left(10 \mathrm{~min}, 95^{\circ} \mathrm{C}\right)$, then 40 cycles of denaturation $\left(30 \mathrm{~s}, 94^{\circ} \mathrm{C}\right)$, primer annealing $\left(40 \mathrm{~s}, 49^{\circ} \mathrm{C}\right)$ and elongation $\left(40 \mathrm{~s}, 72{ }^{\circ} \mathrm{C}\right)$ and fluorescence detection. Cloned nirS and nirK gene fragments (TOPO-TA; Invitrogen, Carlsbad, CA) were used to prepare DNA standards with known quantities of target DNA $\left(10^{3}-10^{8}\right.$ copies $\left.\mu \mathrm{L}^{-1}\right)$. Quality control included post-analytical melt curves and spiking $10^{6}$ nirS $\mu \mathrm{L}^{-1}$ into $\mathrm{UV}$-irradiated environmental DNA extracts.

\subsection{Data analysis}

Data analysis was conducted using SPSS (Chicago, IL; v. 11.0). Gene abundances were normalized to g-dry sediment values. Cumulative distributions of all variables were compared against a normal-distribution function using the Kolmogorov-Smirnov test; as a result, gene abundances and $K_{d e n}$ values required log transformation to better distribute the data. Denitrification rates were calculated from $\mathrm{N}$-values obtained over the entire sample reach; as such, pooled sediment gene-abundance values (per sample location) were used to calculate length-weighted geometric mean abundances of nirS and nirK, which were used in bivariate correlation analysis and principal component analysis (PCA), along with wholestream averages of GPP, $\mathrm{CR}, \mathrm{DOC}, \mathrm{NO}_{3}^{-}, \mathrm{NH}_{4}^{+}$), and SRP. PCA was based on a correlation matrix with Varimax rotation and Kaiser normalisation to maximize differences among loadings.

\section{Results}

\subsection{Distribution of nirS and nirK}

Absolute rates of denitrification, $K_{d e n}$, and stream water chemistry conditions are summarised in Table 1. A close relationship is apparent between ambient $\mathrm{NO}_{3}^{-}$level and the absolute rates of denitrification, which is consistent with results elsewhere (O'Brien et al., 2007; Mulholland et al., 2008). However, we also measured nirS and nirK gene abundances in the water-column and sediment samples to assess how abundances of these genes related to the two measures of denitrification. Before examining relationships between the genes 
and denitrification activity, a preliminary assessment was performed on the spatial distribution of genes in a sub-set of the studied streams.

Fig. 1 presents observed nirS and nirK abundances in the water-column and sediments for the three streams, which shows that gene abundances did vary significantly in the top $3 \mathrm{~cm}$ of the sediment zone in King Creek, Campus Creek, and Ag-North (three very different streams). Water-column gene concentrations were consistently 1-3 orders of magnitude lower than in the sediments, which is expected and reflects the amount of suspended solids in the water-column. Further, nirK abundances were generally higher in the water-column (Campus Creek: $t_{11}=1.79, p=0.11$; all others: $t>3.64, p<0.01$ ) than nirS, which is consistent with past observations that $\operatorname{nirK}$ is often prevails in conditionally $\mathrm{O}_{2}$-exposed environments (Desnues et al., 2007;Knapp et al., 2009).

Given that nir genes were predominantly found in the sediments and that gene levels did not vary significantly in near-surface sediments with depth (ANOVA; $\left.F_{3,10}<1.062 ; p>0.41\right)$, all sediment nirS and nirK gene data were pooled for each sample-site, and then interpolated for all sample and sites along each stream to develop an estimate of the "total" nir-gene levels in each steam. These estimates then were statistically compared with absolute rates of denitrification, $K_{d e n}$, nutrient levels, and other biological activity data to determine trends (Table 1; O’Brien et al., 2007).

\subsection{Comparisons between denitrification rates and gene abundances and environmental conditions}

Bivariate analysis indicated that $K_{d e n}$ significantly correlated with the $\operatorname{nir} S\left(r^{2}=0.80, p=\right.$ $0.006), \operatorname{nirK}\left(r^{2}=0.61, p=0.037\right)$, nirSK (the sum of nirS and $\operatorname{nirK} ; r^{2}=0.78, p=0.009$ ), and SRP $\left(r^{2}=0.57, p=0.049\right)$ levels, whereas absolute denitrification rate only correlated with $\operatorname{SRP}\left(r^{2}=0.80, p=0.006\right)$ and $\mathrm{NO}_{3}^{-}\left(r^{2}=0.57, p=0.049\right)$. Fig. 2 shows a clear and similar relationships exist between the two nir genes and $K_{d e n}$ (i.e., note the correlations roughly parallel each other), which suggests that both genes, within detection limits and gene probes employed here, provide a consistent marker of denitrification gene levels in the streams. Interestingly, no significant correlation was found between $K_{d e n}$ and $\mathrm{NO}_{3}^{-}$, which differs from significant relationships between absolute denitrification rate and $\mathrm{NO}_{3}^{-}$.

Table 2 summarises a PCA performed to further examine relationships suggested by the bivariate correlation analyses by grouping parameters that display similar patterns into discrete components. Specifically, Table 2 shows that $\mathrm{NO}_{3}^{-}$, DOC, and SRP associate with absolute denitrification rate, which have been shown previously to affect denitrification rates in similar streams (Tank and Dodds, 2003;Niyogi et al., 2004;O'Brien et al., 2007). However, the PCA also specifically clusters $K_{d e n}$ with SRP; it also clusters gross primary production (GPP) and community respiration (CR) with each other; and it separates $\mathrm{NH}_{4}^{+}$as a signal component. It is noteworthy that PCA groups SRP with absolute denitrification rate and $K_{d e n}$, implying it contributes to variability in both measures of denitrification activity.

\section{Discussion}

Many environmental factors influence denitrification rates in streams, including dissolved oxygen (DO), DOC, SRP, and $\mathrm{NO}_{3}^{-}$levels (Wallenstein et al., 2006), although how each factor affects in situ rates is not clearly understood. However, only limited biological characterisation of organisms presumed responsible for this reaction has been performed in these experiments, which has limited our ability to fully explain and predict rate data. Therefore, we quantified here nirK and nirS genes in seven streams with differing waterquality conditions and denitrification rates (O'Brien et al., 2007; Knapp et al., 2009) to 
determine possible relationships. As background, Mulholland et al. (2008) had shown that absolute denitrification rates significantly correlate with $\mathrm{NO}_{3}^{-}$levels in streams across many biomes; however, they provide no explanation for why $K_{d e n}$, the intrinsic denitrification rate, does not also correlate with $\mathrm{NO}_{3}^{-}$levels. This is a significant omission because $K_{d e n}$ is an estimate of the optimal rate of $\mathrm{NO}_{3}^{-}$loss per unit distance along a stream, independent of $\mathrm{N}$ level or stream size, which is a potentially more valuable measure of denitrification activity for understanding actual factors that affect in situ rates.

Our data show through bivariate correlation analysis and a PCA that both nir genes significantly correlate/cluster with $K_{d e n}$, but not with absolute rates of denitrification. Further, $K_{d e n}$ significantly correlates SRP, but not with $\mathrm{NO}_{3}^{-}$level (consistent with Mulholland et al., 2008). Therefore, we provide first evidence of a biological explanation for observed in situ $K_{d e n}$ levels. Although such gene abundances do not exactly define the number of responsible denitrifying organisms present (Philippot and Hallin, 2005), they do provide an indirect useful new measure of intrinsic enzymatic capacity for denitrification, which we contend should be used in future studies. The practical question is "why does $K_{d e n}$ correlate with gene abundances", which can be answered when one considers what $K_{d e n}$ actually represents for a stream.

$K_{d e n}$ is the rate of $\mathrm{NO}_{3}^{-}$loss per unit distance along the stream, and is an intrinsic measure of denitrification independent of $\mathrm{N}$ level, stream size, or other explicit habitat factors. As such, $K_{d e n}$ simply clumps all factors that influence denitrification into a single parameter and, in fact, should be most influenced by the limiting factor to denitrification within the system. By analogy, $K_{d e n}$ is the specific substrate utilization rate coefficient from Monod kinetics for the stream. Similar to Monod for biological activity and growth (Monod, 1949), the actual limiting factor in many systems is not always clearly specified, but this factor must be a reflection or controller of the abundance and-or activity of the responsible organisms. Therefore, if nir-gene levels reflect the potential for denitrification in a stream and gene levels are finite, one would expect gene levels to correlate with $K_{d e n}$, the intrinsic denitrification. We suspect the reason why $K_{d e n}$ and $\mathrm{NO}_{3}^{-}$level do not correlate in the most streams is because $\mathrm{NO}_{3}^{-}$is not always the limiting factor to in situ denitrification, especially in the streams with high $\mathrm{NO}_{3}^{-}$levels. Conversely, nirS or nirK gene abundances correlate with $K_{d e n}$ because they best approximate the potential for denitrification, which is a product of present and past habitat and nutrient conditions that have influenced microbial selection. Based on the PCA, one might assume the limiting factor is SRP, or maybe GPP or CP, but this is not certain because other data imply that multiple factors might not be influencing rates (O'Brien et al., 2007).

Regardless, this new work provides a valuable starting point for new investigation on in situ denitrification activity. We contend a comprehensive explanation of denitrification rates and efficiencies only will be possible once molecular and classical limnological approaches are combined. Here we showed reach-scale denitrification efficiency correlates with associated ambient gene abundances. Therefore, future studies should employ a similar approach to finally define dominant factors that are most important to enhancing N-removal from streams, which has both local and global significance to understanding the impact of human activity of the N-cycle.

\section{Acknowledgments}

This research was supported by the United States National Science Foundation (project \#DEB-0111410; the Kansas EPSCoR), the Kansas Technology Enterprise Corporation, and EU Marie Curie Excellence Programme grant MEXT-CT-2006-023469. The authors would like to thank Nicholas Peak, Christina Engemann, Jackie Miller and Teresa Lane who assisted in the field and laboratory support work on the project. 


\section{References}

American Public Health Association (APHA). Standard Methods for the Examination of Water and Wastewater. Washington, DC: American Public Health Association; American Water Works Association, World Environment Federation, 1995.

Bott, TL. Primary productivity and community respiration. In: Hauer, FR.; Lamberti, GA., editors. Methods in Stream Ecology. San Diego, CA, USA: Academic Press; 1996.

Braker G, Fesefeldt A, Witzel KP. Development of PCR primer systems for amplification of nitrite reductase genes (nirK and nirS) to detect denitrifying bacteria in environmental samples. Applied and Environmental Microbiology. 1998; 64:3769-3775. [PubMed: 9758798]

Davidson EA, Seitzinger S. The enigma of progress in denitrification research. Ecological Applications. 2006; 16:2057-2063. [PubMed: 17205889]

Desnues C, Michotey VD, Wieland A, Zhizang C, Fourcans A, Duran R, Bonin PC. Seasonal and diel distributions of denitrifying and bacterial communities in a hypersaline microbial mat (Camargue, France). Water Research. 2007; 41:3407-3419. [PubMed: 17590406]

Dodds WK, Welch EB. Establishing nutrient criteria in streams. Journal of the North American Benthological Society. 2000; 19:186-196.

Galloway JN, Aber JD, Erisman JW, Seitzinger SP, Howarth RW, Cowling EB, Cosby BJ. The nitrogen cascade. Bioscience. 2003; 53:341-356.

Hamilton SK, Ostrom NE. Measurement of the stable isotope ratio of dissolved N-2 in N-15 tracer experiments. Limnology and Oceanography Methods. 2007; 5:233-240.

Henry S, Bru D, Stres B, Hallet S, Philippot L. Quantitative detection of the nosZ gene, encoding nitrous oxide reductase, and comparison of the abundances of $16 \mathrm{~S}$ rRNA, narG, nirK, and nosZ genes in soils. Applied and Environmental Microbiology. 2006; 72:5181-5189. [PubMed: 16885263]

Knapp CW, Dodds WK, Wilson KC, O’Brien JM, Graham DW. Spatial heterogeneity of denitrification genes in a highly homogenous urban stream. Environmental Science \& Technology. 2009; 43:4273-4279. [PubMed: 19603634]

Monod J. The growth of bacterial cultures. Annual Reviews in Microbiology. 1949; 3:371-394.

Mulholland PJ, Valett HM, Webster JR, Thomas SA, Cooper LW, Hamilton SK, Peterson BJ. Stream denitrification and total nitrate uptake rates measured using a field $\mathrm{N}-15$ tracer addition approach. Limnology and Oceanography. 2004; 49:809-820.

Mulholland PJ, Helton AM, Poole GC, Hall RO, Hamilton SK, Peterson BJ, Tank JL, Ashkenas LR, Cooper LW, Dahm CN, Dodds WK, Findlay SEG, Gregory SV, Grimm NB, Johnson SL, McDowell WH, Meyer JL, Valett HM, Webster JR, Arango CP, Beaulieu JJ, Bernot MJ, Burgin AJ, Crenshaw CL, Johnson LT, Niederlehner BR, O’Brien JM, Potter JD, Sheibley RW, Sobota DJ, Thomas SM. Stream denitrification across biomes and its response to anthropogenic nitrate loading. Nature. 2008; 452:202-205. [PubMed: 18337819]

Mulholland PJ, Hall RO, Sobota DJ, Dodds WK, Findlay SEG, Grimm NB, Hamilton SK, McDowell WH, O’Brien JM, Tank JL, Ashkenas LR, Peterson BJ, Poole GC, Valett HM, Webster JR, Arango CP, Beaulieu JJ, Bernot MJ, Burgin AJ, Crenshaw CL, Helton AM, Johnson LT, Niederlehner BR, Potter JD, Sheibley RW, Thomas SM. Nitrate removal in stream ecosystems measured by $15 \mathrm{~N}$ addition experiments: dentrification. Limnology and Oceanography. 2009; 53(3):666-680.

Niyogi DK, Simon KS, Townsend CR. Land-use and stream ecosystem functioning: nutrient uptake in streams that contrast in agricultural development. Archiv für Hydrobiologia. 2004; 180:471-486.

O'Brien JM, Dodds WK, Wilson KC, Murdock JN, Eichmiller J. The saturation of N cycling in Central Plains streams: N-15 experiments across a broad gradient of nitrate concentrations. Biogeochemistry. 2007; 84:31-49.

Philippot L, Hallin S. Finding the missing link between diversity and activity using denitrifying bacteria as a model functional community. Current Opinions in Microbiology. 2005; 8:234-239.

Philippot L. Denitrifying genes in bacterial and archaeal genomes. Biochimica et Biophysica ActaGene Structure and Expression. 2002; 1577:355-376.

Rabalais NN. Nitrogen in aquatic ecosystems. Ambio. 2002; 31:102-112. [PubMed: 12077998] 
Seitzinger S, Harrison JA, Bohlke JK, Bouwman AF, Lowrance R, Peterson B, Tobias C, Van Drecht G. Denitrification across landscapes and waterscapes: a synthesis. Ecological Applications. 2006; 16:2064-2090. [PubMed: 17205890]

Seitzinger S. Nitrogen cycle - out of reach. Nature. 2008; 452:162-163. [PubMed: 18337810]

Sigman DM, Altabet MA, Michener R, McCorkle DC, Fry B, Holmes RM. Natural abundance-level measurement of nitrogen isotopic composition of oceanic nitrate: an adaptation of the ammonia diffusion method. Marine Chemisty. 1997; 57:227-242.

Tank JL, Dodds WK. Responses of heterotrophic and autotrophic biofilms to nutrients in ten streams. Freshwater Biology. 2003; 48:1031-1049.

Tavares P, Pereira AS, Moura JJG, Moura I. Metalloenzymes of the denitrification pathway. Journal of Inorganic Biochemisty. 2006; 100:2087-2100.

Wallenstein MD, Myrold DD, Firestone M, Voytek M. Environmental controls on denitrifying communities and denitrification rates: insights from molecular methods. Ecological Applications. 2006; 16:2143-2152. [PubMed: 17205893] 


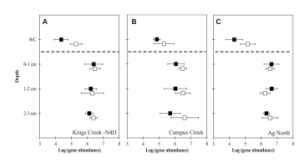

Fig. 1.

Log-transformed $\operatorname{nir} S(\boldsymbol{\square})$ and $\operatorname{nirK}(\square)$ abundances in water-column (per mL) and sediment core (per g-dry sediment) samples taken from Kings, Campus and Ag-North Creeks. 


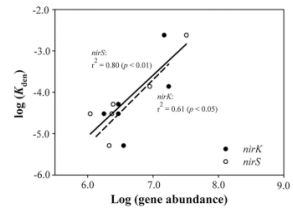

Fig. 2.

Relationship between log-transformed nirS-(०) and nirK-(•) gene abundances and logtransformed denitrification coefficient $\left(K_{d e n}\right)$. Note: Values for Shane Creek were excluded from the graph due to the inability to log-transform the $K_{d e n}$ value $\left(K_{d e n}=.0 \mathrm{~m}^{-1}\right)$. nirS and nirK were $10^{6.2}$ and $10^{6.1}$ genes per g-dry sediment for this stream. 


\section{Table 1}

Chemical, physical, and biological parameters of the seven streams in this study.

\begin{tabular}{|c|c|c|c|c|c|c|c|c|c|}
\hline Stream Name & Location & 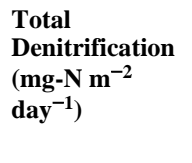 & $K_{d e n}\left(\mathbf{m}^{-1}\right)$ & $\begin{array}{l}\text { DOC } \\
\left(\mathrm{mg} \mathrm{L}^{-1}\right)\end{array}$ & $\begin{array}{l}\mathrm{NO}_{3}^{-} \\
-\mathbf{N} \\
(\boldsymbol{\mu g} \\
\left.\mathbf{L}^{-1}\right)\end{array}$ & $\begin{array}{l}\mathrm{NH}_{4}^{+}-\mathrm{N} \\
\left(\mu \mathrm{g} \mathrm{L}^{-1}\right)\end{array}$ & $\begin{array}{l}\text { SRP } \\
\left(\mu \mathrm{g}-\mathrm{P} \mathrm{L}^{-1}\right)\end{array}$ & $\begin{array}{l}\text { GPP }\left(g-O_{2} m^{-2}\right. \\
\left.\text { day }^{-1}\right)\end{array}$ & $\begin{array}{l}\mathrm{CR}\left(\mathrm{g}-\mathrm{O}_{2} \mathrm{~m}^{-2}\right. \\
\left.\text { day }^{-1}\right)\end{array}$ \\
\hline Shane Creek & Pristine & 0.0 & 0.0 & N/A & 1.2 & 4.7 & 1.0 & 5.4 & -4.5 \\
\hline Kings Creek -N4D & Pristine & 0.2 & $5.13 \times 10^{-5}$ & 3.84 & 8.6 & 0.0 & 0.5 & 6.2 & -3.9 \\
\hline Ag-North & Agricultural & 0.004 & $5.13 \times 10^{-6}$ & 7.36 & 35 & 31.7 & 0.2 & 3.2 & -2.7 \\
\hline Little Kitten Creek & Urban & 12.8 & $1.39 \times 10^{-4}$ & N/A & 168 & 24.2 & 7.2 & 4.3 & -4.2 \\
\hline "The Ditch" & Urban & 43.6 & $2.41 \times 10^{-3}$ & 3.81 & 277 & 28.3 & 35.4 & 12.5 & -7.0 \\
\hline Campus Creek & Urban & 8.8 & $3.05 \times 10^{-5}$ & 10.3 & 2900 & 7.8 & 4.0 & 1.0 & -1.0 \\
\hline Swine Creek & Agricultural & 221 & $3.05 \times 10^{-5}$ & N/A & 21000 & 3.3 & 15.5 & 2.7 & -4.4 \\
\hline
\end{tabular}




\section{Table 2}

Principal component eigenvalues and factor loadings for parameters measured in the seven streams.

\begin{tabular}{lrrrr}
\hline & \multicolumn{4}{l}{ Component } \\
\cline { 2 - 5 } & $\mathbf{1}$ & $\mathbf{2}$ & $\mathbf{3}$ & $\mathbf{4}$ \\
\hline \% of Variance & $\mathbf{3 4 . 5}$ & $\mathbf{2 8 . 7}$ & $\mathbf{2 3 . 6}$ & $\mathbf{9 . 2}$ \\
\hline Total denitrification & .578 & $\mathbf{. 8 0 0}$ & -.038 & -.147 \\
$K_{\text {den }}$ & $\mathbf{. 9 4 9}$ & .151 & .194 & -.175 \\
nirK & $\mathbf{. 9 1 3}$ & -.114 & .027 & .260 \\
nirS & $\mathbf{. 8 9 3}$ & -.021 & .410 & .149 \\
nirSK & $\mathbf{. 9 4 2}$ & -.056 & .220 & .211 \\
GPP & .350 & -.409 & $\mathbf{. 8 3 1}$ & -.072 \\
CR & .168 & -.086 &. $\mathbf{9 7 8}$ & .061 \\
GPP:CR Ratio & .501 & -.790 & .083 & -.284 \\
DOC & -.157 & $\mathbf{. 7 8 6}$ & -.387 & .311 \\
$\mathrm{NO}_{3}^{-}$ & .259 & $\mathbf{. 8 7 0}$ & -.360 & .047 \\
$\mathrm{NH}_{4}^{+}$ & .265 & .139 & -.126 & $\mathbf{. 9 1 2}$ \\
$\mathrm{SRP}$ & & & & \\
\hline
\end{tabular}

Note: Parameters with significant loadings within each component are highlighted in bold text. 